\title{
GANTI KERUGIAN TERHADAP ANAK KORBAN TINDAK PIDANA PENCABULAN
}

\author{
Achmad Murtadho \\ Fakultas Hukum, Universitas Brawijaya Malang \\ e-mail: tranetadho@gmail.com
}

disampaikan 13/4/2020 - di-review 4/6/2020 - diterima 31/5/2021

DOI: $10.25123 /$ vej.v7i1.3954

\begin{abstract}
Children's rights, as victim (of sexual offences) or perpetrator of crime, are not yet well secured or protected by law. This issue will be discussed by examining closely the substantive and procedural rules-regulation in the Law of Child Protection (no. 23 of 2002) and Law on Child Court (no. 11 of 2012). In addition, legal practice about children court shall also be highlighted. The author suggest that the prevailing substantive and procedural law has not yet be made adequately in response to the special needs of children victims of sexual abuse as well as accommodating the need for sufficient and fair compensation. It is as it is, due, amongst others, for the lack of victim perspective in the making of the children court system and how this system is being practiced.
\end{abstract}

Keywords:

children before and facing the law, child victims of crime, compensation

\begin{abstract}
Abstrak
Hak-hak anak yang berhadapan dengan hukum termasuk sebagai korban tindak pidana percabulan belum mendapatkan perlindungan hukum semestinya. Persoalan ini akan ditelaah dengan menelusuri aturan-aturan dalam UU Perlindungan Anak (No. 23 tahun 2002) dan UU Sistem Peradilan Pidana Anak (UU 11 tahun 2012) dan juga akan dibandingkan dengan praktik peradilan anak. Satu temuan penting adalah bahwa hukum (substantive dan procedural) yang ada belum responsive terhadap kepentingan anak korban tindak pidana dan juga belum mengakomodasi pengaturan ganti kerugian. Selain itu, pengaturan yang terfokus pada perlindungan anak belum memadai satu dan lain karena belum adanya perspektif korban dalam pembuatan aturan maupun praktik peradilan anak.
\end{abstract}

Kata Kunci: anak yang berhadapan dengan hukum, anak korban tindak pidana, ganti kerugian

\section{Pendahuluan}

Anak merupakan bagian dari generasi muda yang harus dilindungi dan diharapkan bagi kemajuan bangsa. Adapun perlindungan bagi anak meliputi segala kegiatan untuk menjamin dan melindungi Anak dan hak-haknya agar dapat hidup, tumbuh, dan berkembang secara optimal serta mendapat perlindungan dan diskriminasi. ${ }^{1}$ Pelindungan terhadap Anak hakekatnya termuat pada anak yang berhadapan dengan peradilan pidana serta Anak yang berhadapan dengan hukum, baik sebagai Pelaku maupun Korban. Pada Peraturan Perlindungan Anak bahwa

\footnotetext{
Undang Undang Nomor 23 Tahun 2002 Bab I Ketentuan Umum Pasal 1 Nomer 2 tentang Perlindungan Anak
} 
Sistem Peradilan Anak telah mengatur tentang hak-hak Pelaku Tindak Pidana pada Anak yang berhadapan dengan Hukum bagi Pelaku terdapat beberapa macam perlindungan dari mulainya penerapan pidana secara khusus melalui penyelesaian perkara Diversi ${ }^{2}$ maupun penyelesaian perkara secara Restoratif ${ }^{3}$. Sedangkan Hak-hak Anak Korban meliputi Ganti Kerugian (Restitusi), Kompensasi serta Rehabilitasi. ${ }^{4}$ Namun keberadaan dalam pemenuhan hak-hak Korban belum memberikan implikasi peraturan perlindungan Korban secara efektif sehingga keberadaan Korban hanya bersifat pasif terlebih pada kasus pencabulan yang melibatkan Korban Anak, yang mengalami penderitaan lebih berat secara psikis terhadap trauma sejak dini.

Putusan Pengadilan Negeri Pekanbaru menunjukkan terdapat perkara tindakan kejahatan seksual pencabulan terhadap Anak Korban yang isi pokoknya yaitu Pelaku anak yang berinisial D yang berumur 16 Tahun telah melakukan perbuatan Asusila berupa pencabulan terhadap Anak Korban Laki-Laki (Korban) berusia 3 (tiga) tahun. Kejadiannya yaitu pada saat Korban bermain dan Pelaku Anak D mengajaknya ke kamar. Sehingga terjadilah perbuatan pencabulan yang dilakukan Pelaku Anak dengan memasukkan kelamin Pelaku kedalam dubur Anak Korban. Dan akhirnya Korban melapor kepada orang tuanya. Pelaku ditangkap dan dilakukan penyidikan, penyelidikan, tuntutan hingga putusan pada Pengadilan negeri Pekanbaru. Sesuai dengan putusan Nomor 13/Pid.SusAnak/2017/PN.Pbr yang Memerintahkan agar Terdakwa Anak dikeluarkan dari tahanan dengan syarat khusus supaya Anak menjalani 10 (bulan) Pembinaan di dalam Lembaga Sosial dan menjatuhkan pula pidana Pelatihan Kerja kepada Anak selama 2 (dua) bulan. Putusan Hakim tersebut menyatakan bersalah dan sesuai

2 Diversi adalah pengalihan penyelesaian perkara Anak dari proses peradilan pidana ke proses di luar peradilan pidana, Bab I Undang-Undang Republik Indonesia Nomor 11 Tahun 2012 Tentang Sistem Peradilan Pidana Anak, Pasal 1, Ketentuan Umum.

3 Restoratif adalah penyelesaian perkara tindak pidana dengan melibatkan pelaku, korban, keluarga pelaku/korban, dan pihak lain yang terkait untuk bersama-sama mencari penyelesaian yang adil dengan menekankan pemulihan kembali pada keadaan semula, dan bukan pembalasan, Bab I Pasal 1, Ketentuan Umum, Undang-Undang Republik Indonesia Nomor 11 Tahun 2012 Tentang Sistem Peradilan Pidana Anak.

4 Undang-Undang Republik Indonesia Nomor 11 Tahun 2012 Tentang Sistem Peradilan Pidana Anak 
pada Undang-Undang Nomor 35 Tahun 2014 tentang perubahan atas Undang Undang nomor 23 Tahun 2002 tentang Perlindungan Anak Pasal 82 ayat (1) telah terbukti dan bersalah dalam perbuatan yang dilakukan melakukan perbuatan membujuk membiarkan anak untuk pada tindak pidana perbuatan cabul. ${ }^{5}$

Putusan Nomor 13/Pid.Sus-Anak/2017/PN.Pbr Hakim Pengadilan Negeri Pekanbaru memutus penyelesaian perkara secara komulatif6 dengan putusan dijatuhkannya sanksi melalui Kerja Sosial, yang dikarenakan Pelaku merupakan masuk pada usia Anak, namun pada putusan tersebut sama sekali tidak memuat pemenuhan hak-hak pada Anak Korban dalam tindak pidana cabul. Hal tersebut justru akan menjadi preseden yang buruk bagi keadilan di Indonesia. Putusan tersebut bertentangan dengan Asas-asas pada sistem perlindungan Anak atau tidak konsisten inkonsisten ${ }^{7}$ dalam pelaksanaan perkara pidana terutama pada Korban pencabulan bagi Anak.

Aparat Penegak hukum dalam peradilan pidana pada kenyataannya sering tidak melihat dirinya mewakili korban sehingga menganggap bahwa jalan terbaik untuk menolong Korban adalah dengan menjatuhkan pidana kepada Pelaku Kejahatan, dan pada putusannya Hakim lebih memilih terpeliharanya ketertiban di masyarakat. Proses peradilan cenderung berfokus pada perbuatan Pelaku dengan rumusan pasal hukum pidana telah dilanggar atau tidaknya perbuatan pidana. Hal seperti itu tampak hukum acara pidana hanya untuk mencari kebenaran materiil sebagai kebenaran yang jujur dan tepat, namun perlindungan Hak Asasi Manusia tidak sepenuhnya tercapai terutama pada hak-hak Korban. Hal ini terlihat dari putusan Nomor 13/Pid.Sus-Anak/2017/PN.Pbr Hakim Pengadilan Negeri Pekanbaru atau bahkan putusan perkara pidana Anak yang lainnya yang mana penegak hukum mengkondisikan korban sebatas hanya sebagai saksi pada proses persidangan, tanpa mengakaji penderitaan serta hak korban untuk

Undang-Undang Nomor 35 Tahun 2014 Tentang Perubahan Atas Undang-Undang Nomor 23 Tahun 2002 Tentang Perlindungan Anak.

6 Pasal 71 Ayat (3) Undang-Undang Nomor 11 Tahun 2012 Tentang Sistem Peradilan Anak yang artinya kumulatif (tambah/ganda dalam (KBBI)) berupa penjara dan denda, pidana denda diganti dengan pelatihan kerja.

7 Tidak selaras atau tidak sesuai asas, Surawan Maktinus, Kamus Terapan. Persada Media Pustaka, Jakarta, 2008, Hlm 30 
memperoleh keadilan dan akses untuk mengetahui bagaimana keadilan tersebut dijalankan sebagaimana mestinya pada putusan Pengadilan. Oleh karena itu, selama ini pertanggungjawaban pidana pada putusan pengadilan terhadap Korban bukan menjadi pertanggungjawaban terhadap kerugian/penderitaan korban secara langsung dan konkret, tetapi tertuju pada pertanggungjawaban pribadi yang hanya bersifat fakultatif yang berarti Ganti Kerugian (Restitusi) tidak memiliki sifat keharusan atau imperatif. Hal ini yang menjadi inkonsisten serta menjadi kelemahan peraturan mengenai Perlindungan Korban khususnya pada peradilan pidana Anak.

Atas persepektif tersebut apabila dikaitkan dengan peraturan perundangundangan mengenai perlindungan Anak Korban maka akan terlihat bagaimana hak-hak perlindungan Anak Korban tersebut dapat diterapakan pada proses peradilan Anak. Bentuk pelindungan Anak Korban meliputi Ganti Kerugian (Restitusi), Kompensasi serta Rehabilitasi. ${ }^{8}$ Berikut aturan mengenai hak-hak atas ganti kerugian Anak Korban diantaranya yaitu :

Pertama, Undang-Undang Nomor 31 Tahun 2014 tentang Perlindungan Saksi dan Korban pada (UUPSK) mengenai Perolehan hak Korban dalam mendapatkan hak ganti-tugi (Restitusi) yang termuat Pada Pasal 7 srta pada Pasal 8 yang telah disisipkan diantarnya secara 2 (dua) pasal, yakni Pasal 7A dan Pasal 7B yang berbunyi bahwa Korban tindak pidana telah berhak memperoleh Restitusi yaitu berupa :

a) Ganti kerugian atas kehilangan secara ekonomi pada kekayaan maupun penghasilan;

b) Ganti kerugian dari akibat yang ditimbulkan ketika korban mengalami penderitaan yang berkaitan secara langsung sebagai dampak tindak pidana kejahatan; dan/atau

c) Perawatan medis pada fisik dan/atau secara psikologis maupun pada kejiwaan dengan bentuk Penggantian biaya yang diterima. ${ }^{9}$

Kedua, Undang Undang nomor 23 Tahun 2002 tentang Perlindungan Anak juga mengatur pemenuhan hak-hak Restitusi Korban Anak pada Pasal 71 D Ayat

8 Undang-Undang Republik Indonesia Nomor 11 Tahun 2012 Tentang Sistem Peradilan Pidana Anak

9 Undang-Undang (UU) Perlindungan Anak Tahun 2014 Nomor 31 Tentang Perubahan Atas Tahun 2016 Nomer 13 
(1) mengatur Hak Restitusi Korban Anak Ayat (2) mengenai Hak restitusi anak korban Pasal 59 pada huruf b, huruf d, huruf f, huruf h.

Huruf i dan huruf j juga mengatur, yang berbunyi Setiap Anak yang menjadi korban mempunyai hak atas ganti kerugian (restitusi) untuk mengajukan ke pengadilan yang telah menjadi tanggung jawab bagi pelaku kejahatan. ${ }^{10}$

Ketiga, Secara Implementasi terdapat pada Pemerintah Republik Indonesia Nomor 43 Tahun 2017 Tentang Pelaksanaan Restitusi Bagi Anak pada Pasal 2 mengenai tata cara pengajuan permohonan Restitusi Bagi Anak Korban dilakukan melalui permohonan ganti kerugian (Restitusi) yang diajukan oleh pihak Korban, pihak korban yang dimaksud adalah (Orang Tua/Wali Anak Korban, Ahli Waris Anak, Orang yang diberi Kuasa) selain itu juga dapat diajukan oleh lembaga perlindungan Saksi Korban.

Tuntutan ganti kerugian akibat perbuatan tindak pidana melalui penggabungan gugatan perkara pidana pada pihak Korban diatur dalam Pasal 98 Ayat (1) KUHAP yang menyebutkan bahwa :

Jika suatu perbuatan yang menjadi dasar dakwaan di dalam suatu pemeriksaan perkara pidana oleh pengadilan negeri menimbulkan kerugian bagi orang lain, maka hakim ketua sidang atas permintaan orang itu dapat menetapkan untuk menggabungkan perkara gugatan ganti kerugian kepada perkara pidana itu.

Berdasarkan Undang-Undang Nomor 8 Tahun 1981 tentang Kitab Undang-Undang Hukum Acara Pidana (KUHAP) Pasal 98 Ayat (1), memberi kesempatan kepada Korban untuk menggabungkan perkara gugatan ganti kerugian kedalam proses peradilan pidana dan ganti kerugian ini dipertanggung jawabkan pada pelaku tindak pidana, namun pasal 98 Ayat 1 KUHAP terdapat pembatasan yang tidak memiliki sifat imperatif atau keharusan. Hakim pada ketentuan pokok kekuasaan kehakiman tidak mengatur mengenai ganti kerugian pada kepentingan korban, namun hanya berorientasi pada Pelaku. Begitupun juga lembaga kejaksaan sebagai lembaga penegak hukum yang jarang sekali memberikan sanksi khusus permohonan gugatan ganti kerugian kepada Pelaku untuk Korban, dikarenakan lembaga pemerintahan yang fungsinya hanya untuk melakukan penuntutan 10 Id 
pidana, membuat aturan atau pedoman keputusan yang dilaksanakan dalam suatu organisasi dan melalui administrasi pembuktian pada proses peradilan.

Pemberian informasi mengenai hak Korban dapat diberikan melalui Lembaga Kepolisian serta melalui Lembaga Perlindungan Saksi Korban (LPSK) pada sejak dilakukannya penyidikan. Sedangkan, mengenai hak korban untuk mengajukan permohonan restitusi maupun kompensasi tidak berdasarkan atas tugas dan kewajiban dari lembaga Lembaga Kepolisian serta LPSK namun masih atas permohan dari pihak Korban, atas dasar hal tersebut termuat pada Pasal 7-8 Undang-Undang Nomor 31 Tahun 2014 Tentang Perubahan Atas Undang-Undang Nomor 13 Tahun 2006 Tentang Perlindungan Saksi Dan Korban dan Pasal 4 Peraturan Pemerintah Republik Indonesia Nomor 43 Tahun 2017 Tentang Pelaksanaan Restitusi Bagi Anak. Apabila permohonan tidak diajukan oleh pihak Anak Korban maka Lembaga Kepolisian serta LPSK akan bersifat pasif tidak akan memproses permohonan restitusi Anak Korban, yang hal tersebut sama sekali tidak mencerminkan asas keadilan serta asas kepentingan terbaik bagi Anak.

Bagi Peneliti permasalahanya adalah Kepolisian, LPSK, Penyidik dan Penuntut Umum tidak mempunyai kewajiban atau lalai untuk memberitahukan kepada pihak Korban, dan tidak ada ketegasan pada peraturan perundangundangan mengenai Perlindungan Anak Korban untuk meperoleh hak ganti kerugian. Hal ini dapat menyebabkan anomali dari Undang-Undang Nomor 35 Tahun 2014 tentang perubahan atas Undang Undang nomor 23 Tahun 2002 tentang Perlindungan Anak (UUPA), Undang-Undang Nomor 31 Tahun 2014 tentang Perlindungan Saksi dan Korban pada (UUPSK) serta Peraturan Pemerintah Nomor 43 Tahun 2017 Tentang Pelaksanaan Restitusi Bagi Anak, yang Menjadi Korban Tindak Pidana Pencabulan bahkan secara keseluruhan dalam melaksanakan permohonan ganti kerugian (restitusi) melalui tahap penyidikan sampai penuntutan menjadi gugur. Sehingga, Putusan Nomor 13/Pid.SusAnak/2017/PN.Pbr Hakim Pengadilan Negeri Pekanbaru terdapat inkonsisten yang menjadikan kekaburan hukum (vaqueness) pada proses peradilan Anak.

Jalur peradilan pidana Anak pada Korban Kejahatan seksual lebih dirasa memberatkan dan kurang memuaskan rasa keadilan baik secara materiel 
kerugian biaya perawatan luka/medis serta psikis seperti trauma pada psikologis bagi diri Anak Korban. Bahwa Putusan Nomor 13/Pid.Sus-Anak/2017/PN.Pbr Hakim Pengadilan Negeri Pekanbaru kurang mempertimbangkan faktor filosofis keadilan yang cenderung represif dan hanya mempertimbangkan faktor normatif hukum lainnya pada Pelaku Tindak Pidana. Dalam hal ini realitas sosial perlindungan Anak Korban mengalami degradasi karena adanya kekurangan atau hambatan dalam perundang-undangan, sehingga kurang mengakomodasi hak-hak korban.

\section{Pembahasan}

\section{Perlindungan Anak Korban Tindak Pidana Pencabulan Anak Dalam KUHP, KUHAP, dan Perundang-undangan lainnya}

Hukum Perlindungan Anak adalah hukum yang menjadi dasar dan pedoman melindungi, mengatur, dan menjamin anak dapat melaksanakan hak dan kewajibannya secara seimbang dan manusiawi positif.11 Perlindungan hukum terhadap anak dalam kaitannya dengan fenomena kejahatan pencabulan adalah perlindungan yang dilakukan sebelum dan setelah anak menjadi korban cabul. Undang-Undang Perlindungan Anak menegaskan bahwa pertanggungjawaban orang tua, keluarga, masyarakat, pemerintah dan negara merupakan rangkaian kegiatan yang dilaksanakan secara terus menerus demi terlindunginya hak-hak anak. Adapun hak-hak Perlindungan Anak sebagai korban cabul di bagi menjadi 3 yaitu 1. Ganti Kerugian (Restitusi), 2. Rehabilitasi, dan 3. Kompensasi.

Perlindungan Korban pada Undang-Undang Sistem peradilan Anak Pasal 18 menyebutkan bahwa Pembimbing Kemasyarakatan, Pekerja Sosial Profesional dan Tenaga Kesejahteraan Sosial, Penyidik, Penuntut Umum, Hakim, dan Advokat atau pemberi bantuan hukum mewajibakan untuk memerhatikan kepentingan korban. Hal ini Anak sebagai Pihak Korban dan/atau Anak berhak atas berbagai semua bentuk perlindungan maupun hak-hak lain yang diterima sebagai pihak Korban dan/atau Saksi yang diatur telah dalam ketentuan peraturan perundangundangan.

11 Arif Gosita, Peradilan Anak di Indonesia, Mandar Maju, 1996, Bandung, hlm 177. 
Kitab Undang-Undang Hukum Pidana telah diakomodasi perhatian terhadap Korban yakni Pasal 48 ke 9 yang maksudnya bahwa dalam proses pemidanaan hakim wajib dalam mempertimbangkan pengaruh dari tindak kejahatan tindak pidana terhadap korban dan/atau bagi pihak keluarga korban yang mengalami.

Perlindungan Hukum terhadap Sistem Peradilan Anak pada Pasal 2 UU Nomor 23 Tahun 2002 dilaksanakan beradasarkan pada Asas perlindungan, pada Asas keadilan non diskriminasi bagi Anak, kepentingan terbaik bagi kehidupan anak, penghargaan terhadap prilaku anak, bagi kelangsungan hidup bagi Anak, pembinaan terhadap Anak, bimbingan kepada Anak, perampasan kemerdekaan serta pemidanaan sebagai upaya jalan akhir serta penghindaran segala bentuk pembalasan. Dilanjut pada pasal 18 Sistem Peradilan Anak UU Tahun 2002 Nomer 23 wajib memperhatikan kepentingan terbaik bagi anak dan mengusahakan kekeluargaan tetap terpelihara. Serta pasal 90 Sistem Peradilan Anak mengenai anak korban dan saksi berhak atas :

\section{1) Pemberian Restitusi}

Pada pemberian Restitusi bagi Anak terdapat PP Nomor 43 mengenai pelaksanaan ganti kerugian restitusi pada anak yang menjadi korban tindak pidana dijelaskan bahwa restitusi merupakan pembayaran ganti kerugian yang diberikan kepada pelaku atas perbuatan yang menghasilakn kerugian secara materiil maupun kerugian secara immateriil ${ }^{12}$ yang diderita oleh Anak Korban. Adapun hak-hak retitusi yang diatur dalam :

a. Undang-Undang Nomor 31 Tahun 2014 tentang perubahan atas Undang Undang nomor 13 Tahun 2006 tentang Perlindungan Saksi dan Korban;

b. Peraturan Pemerintah Nomor 44 Tahun 2008 tentang Pemberian Kompensasi, Restitusi dan bantuan kepada saksi dan korban;

c. Peraturan Pemerintah Nomer 43 Tahun 2017 tentang pelaksanaan restitusi bagi anak yang menjadi korban tindak pidana.

12 Peraturan Pemerintah Nomer 43 Tahun 2017 Tentang Pelaksanaan Restitusi Bagi Anak Yang Menjadi Korban Tindak Pidana 
Undang-Undang Nomor 31 Tahun 2014 tentang perubahan atas Undang Undang nomor 13 Tahun 2006 tentang Perlindungan Saksi dan Korban pada pasal 7 A bahwa Korban dalam Tindak pidana berhak memperoleh ganti kerugian berupa Restitusi mengenai kekayaan atau pengahsilan, ganti kerugian akibat dari penderitaan kejahatan tindak pidana serta penggantian biaya perawatan medis. Hal tesebut berdasarkan keputusan LPSK dan Pengadilan. Undang-Undang Nomor 35 Tahun 2014 tentang perubahan atas Undang Undang nomor 23 Tahun 2002 tentang Perlindungan Anak pada pasal 71 D yang berisi bahwa Setiap Anak yang telah menjadi Korban pada kejahatan tindak pidana berhak mengajukan ke pengadilan negeri berupa hak atas (ganti kerugian) restitusi yang menjadi tanggung jawab pelaku kejahatan tindak pidana. ${ }^{13}$

Secara lebih khusus Perlindungan UUPA Nomor 23 Tahun 2014 juga mengatur pemenuhan hak-hak Restitusi Anak Korban pada Pasal 71 D Ayat (1) mengatur Hak Restitusi Anak Korban Ayat (2) mengenai Hak restitusi Anak Korban Pasal 59 pada huruf b, huruf d, huruff, huruf h.

Huruf i dan huruf j juga mengatur, yang berbunyi Setiap Anak yang menjadi korban mempunyai hak atas ganti kerugian (restitusi) untuk mengajukan ke pengadilan yang telah menjadi tanggung jawab bagi pelaku kejahatan. ${ }^{14}$

Sebagai bentuk penerimaan Restitusi bagi Anak yang menjadi korban tindak pidana yaitu berupa:

a. Perolehan ganti kerugian atas kehilangankekayaan secara ekonomi;

b. Perolehan ganti kerugian atas penderitaan sebagai dampak akibat tindak pidana kejahatan; dan/atau

c. penggantian biaya untuk perawatan medis dan/atau psikologis. ${ }^{15}$

Bentuk ganti kerugian tersebut terdapat pada Peraturan mengenai Perlindungan Saksi dan Korban pada (UUPSK) Nomor 31 Tahun 2014 Perolehan hak Korban dalam mendapatkan hak ganti-tugi (Restitusi) yang termuat Pada Pasal 7 srta pada Pasal 8 yang telah disisipkan diantarnya secara 2 (dua) pasal,

13 Undang-Undang Nomor 35 Tahun 2014 Tentang Perubahan Atas Undang-Undang Nomor 23 Tahun 2002 Tentang Perlindungan Anak;

14 Id.

15 Peraturan Pemerintah Republik Indonesia Nomor 43 Tahun 2017 Tentang Pelaksanaan Restitusi Bagi Anak Pada pasal 3 ayat (1) . 
yakni Pasal 7A dan Pasal 7B yang berbunyi bahwa Korban tindak pidana telah berhak memperoleh Restitusi yaitu :

a) Ganti kerugian atas kehilangan secara ekonomi pada kekayaan maupun penghasilan;

b) Ganti kerugian dari akibat yang ditimbulkan ketika korban mengalami penderitaan yang berkaitan secara langsung sebagai dampak tindak pidana kejahatan, dan/atau ;

c) Perawatan medis pada fisik dan/atau secara psikologis maupun pada kejiwaan dengan bentuk Penggantian biaya yang diterima. ${ }^{16}$

Ketika permohonan tersebut dilakukan sebelum putusan pengadilan, dapat diajukan melalui 2 (dua) tahap yaitu melalui proses penyidikan atau penuntutan. ${ }^{17}$ Pada tahap permohonan restitusi sebelum putusan yaitu pada penyidikan, maka penyidik dan penuntut memberitahukan kepada pihak korban mengenai hak Anak yang menjadi Korban. ${ }^{18}$ Mekanisme pengajuan perolehan kompensasi tersebut yaitu diajukan oleh Korban kepada Pengadilan melalui LPSK. Memberikan bantuan hukum dan pendampingan hukum agar kasus dapat diselesaikan secara hukum. Pendampingan ini dapat dilakukan mulai dari pendampingan pelaporan dan pembuatan Berita Acara Pemeriksaan (BAP) di Kepolisian, koordinasi dengan pihak Kejaksaan hingga pendampingan korban. ${ }^{19}$

Dengan dalih tugas dan fungsi pada (LPSK) dalam membantu hak-hak dari Korban, tetapi ketika dalam praktiknya Korban merasa rumit dengan persyaratan serta meknisme dalam memperoleh hak-hak kompensasi serta ketidaktahuan Korban dan/atau Keluarga Koban sehingga lebih memilih mengabaikan hak-hak atau asas yang terbaik bagi kepentingan Anak yang termuat pada sistem peradilan

16 Undang-Undang (UU) Perlindungan Anak Tahun 2014 Nomor 31 Tentang Perubahan Atas Tahun 2016 Nomer 13

17 Peraturan Pemerintah Republik IndonesiaNomor 43 Tahun 2017 Tentang Pelaksanaan Restitusi Bagi Anakyang Menjadi Korban Tindak Pidana :yang berbunyi Permohonan Restitusi kepada pengadilan sebagaimana dimaksud ayat (1) yang diajukan sebelum putusan pengadilan, diajukan melalui tatrap: a penyidikan; atau b. Penuntutan Pasal 5 Ayat (2).

18 Peraturan Pemerintah Republik Indonesia Nomor 43 Tahun 2017 Tentang Pelaksanaan Restitusi Bagi Anak yang Menjadi Korban Tindak Pidana Pasal 9 dan Pasal 14.

19 Nyoman Mas Aryani, Perlindungan Hukum Terhadap Anak Sebagai Korban Kekerasan Seksual Di Provinsi Bali, Jurnal Ilmiah Fakultas Hukum Universitas Udayana Kertha Patrika Volume 38, Nomor 1, Januari-April 2016, hlm 12. 
Anak. Kompensasi yang berkarakter perdata diberikan proses peradilan pidana dengan penggabungan ganti kerugian.

Kompensasi dari Negara ini merupakan tanggungan negara atas kewajiban gantirugi yang sebenarnya dibebankan kepada Pelaku melalui pengadilan. Hal ini merupakan bentuk penemuan atau implikasi dari pengakuan negara atas ketidakmampuannya dalam menjalankan tugas dalam melindungi korban dan mencegah timbulnya pada kejahatan. ${ }^{20}$

Namun dari beberapa peraturan mengenai pemberian hak restitusi bagi korban tidak tercantum pada Sistem peradilan Anak, hanya saja dalam UndangUndang mencantumkan hak-hak Korban ketika mengadakan perdamaian melalui diversi dengan kesepakatan persetujuan korban dan/atau keluarga anak korban pada nilai kerugian. Dan ganti kerugian tersebut dapat digabungkan dengan perkara pidana yang dijalani sesuai pada KUHP UU Nomer 8 Tahun 1981 yang menjelaskan bahwa yaitu : Jika suatu perbuatan yang mendasarkan ketika dalam dakwaan pada suatu perkara mulai dari pemeriksaan pidana oleh pengadilan negeri yang menimbulkan kerugian bagi orang lain, maka hakim ketua sidang atas permintaan orang tersebut dapat menetapkan digabungnya perkara gugatan ganti kerugian tersebut kepada perkara pidana yang dijalani. Maksud dari kerugian bagi orang lain itu yaitu bagi Korban kejahatan Tindak Pidana. ${ }^{21}$

\section{2) Rehabilitasi}

Rehabilitasi adalah penyembuhan melalui jaminan keselamatan secara fisik yaitu pada tubuh, secara mental yaitu pada kejiwaan Anak, maupun sosial dampakpergaulan di masyarakat. Dalam pelaksanaannya terdapat pada pemberian Kompensasi, Restitusi PP Tahun 2008 nomor 44. Hal tersebut tercantum pada pasal 38 dan pasal 39 bahwa bantuan ditetapkan dengan keputusan LPSK berdasarkan surat dokter tempat korban memperoleh perawatn serta pengobatan. Undang-Undang Tahun 2012 sistem peradilan anak nomor 11, pada pasal 89 bab VII menyatakan bahwa Anak Korban dan/atau Anak Saksi berhak atas segala perlindungan, upaya pemulihan rehabilitasi medis serta

20 Maya Indah, Supra no. 2, hlm 138.

21 Undang-Undang Nomer 8 Tahun 1981 Tentang Kitab Undang-Undang Hukum Acara Pidana 
pemulihan rehabilitasi secara sosial dengan jaminan keselamatan baik fisik keadaan Korban, mental terhadap Jiwa Korban maupun sosial pada masyarakat.

\section{3) Pemberian Kompensasi}

Kompensasi adalah ganti kerugian yang diberikan oleh negara karena pelaku tidak mampu memberikan ganti kerugian sepenuhnya yang menjadi tanggung jawabnya kepada Korban atau Keluarganya. ${ }^{22}$ Dalam hal ini kejahtan seksual cabul pada anak merupakan tergolong kasus HAM berat yang seharusnya mendapat kompensasi melaui lembaga LPSK. Pemberian kompensasi berhak diberikan pada kasus HAM yang Berat, korban pelanggaran yang berat meliputi korban pada tindak pidana teror atau terorisme, pada korban tindak pidana perdagangan orang atau eksploitasi, serta pada korban tindak pidana kekerasan seksual dalam hal ini pemerkosaan atau cabul pada Anak dan Korban penganiayaan berat. Pemberian komepnasasi tersebut tertuang pada Perlindungan Saksi dan Korban Undang-Undang Nomor 31 tahun tahun 2016 tentang Perlindungan saksi dan korban.

Ketentuan korban mendapatkan kompensasi, perolehan hak Korban mendapatkan kompensasi termuat bahwa setiap Korban yang telah mendapatkan Pelanggaran kasus HAM (hak asasi manusia) yang berat dan pada Korban tindak pidana perbuatan teror atau terorisme selain mendapatkan hak termasuk pada sebagaimana dimaksud dalam Pasal 5 dan juga Pasal 6, juga berhak atas Kompensasi, hal itu termuat pada Perlindungan Saksi Korban pasal 7.23

Kompensasi merupakan bentuk ganti kerugian yang diberikan oleh negara dikarenakan pelaku tidak mampu untuk memberikan ganti kerugian kepada pihak Korban dan/atau Keluarga Korban yang sepenuhnya menjadi tanggung jawabnya Pelaku. ${ }^{24}$

22 Undang-Undang Republik Indonesia Nomor 31 Tahun 2014 Tentang Perubahan Atas UndangUndang Nomor 13 Tahun 2006 Tentang Perlindungan Saksi Dan Korban Ketentuan Pasal 1 Nomer 10.

23 Id. Pasal 7

24 Ketentuan Pasal 1 Nomer 10 penjelasan Kompensasi pada Undang-Undang Tentang Perubahan Atas Undang-Undang Nomor 13 Tahun 2006 Tentang Perlindungan Saksi Dan Korban 
Pemberian kompensasi tersebut didapatkan berdasarkan keputusan Pengadilan yang telah berkekuatan hukum tetap. Secara khusus terdapat ketentuan korban mendapatkan kompensasi, perolehan hak Korban mendapatkan kompensasi termuat pada pasal 7 yang berbunyi Setiap Korban pelanggaran hak asasi manusia yang berat dan Korban tindak pidana terorisme selain mendapatkan hak sebagaimana dimaksud dalam Pasal 5 dan Pasal 6, juga berhak atas Kompensasi. ${ }^{25}$

Kompensasi dari Negara ini merupakan tanggungan negara atas kewajiban ganti rugi yang sebenarnya dibebankan kepada pengadilan kepada pelaku. Hal ini merupakan implikasi dari pengakuan negara atas ketidakmampuannya dalam menjalankan tugas melindungi korban dan mencegah terjadinya kejahatan. ${ }^{26}$ Pemberian kompensasi tidak diatur dalam peraturan Undang-Undang Perlindungan Anak maupun Undang-Undang Sistem Peradilan Pidana Anak. Aturan pemberian kompensasi masih mengunakan aturan Undang-Undang Republik Indonesia Nomor 31 Tahun 2014 Tentang Perubahan Atas UndangUndang Nomor 13 Tahun 2006 Tentang Perlindungan Saksi Dan Korban serta pelaksanaanya pada Peraturan Pemerintah Republik Indonesia Nomor 44 Tahun 2008 Tentang Pemberian Kompensasi, Restitusi, dan Bantuan Kepada Saksi Dan Korban, sehingga pemberian kompensasi pada Anak Korban kurang memenuhi Asas Kepentingan Terbaik bagi Anak. Untuk pengajuan memperoleh Kompensasi terdapat pada Peraturan Pemerintah Republik Indonesia Nomor 44 Tahun 2008 Tentang Pemberian Kompensasi, Restitusi, dan Bantuan Kepada Saksi Dan Korban Pasal 2 yang menyebutkan bahwa pemberian kompensasi diajukan oleh Korban, Keluarga atau kuasa Khususnya, kemuadian diajukan ke Pengadilan melalui LPSK. Pengajuan tersebut dilakukan pada saat sebelum dibacakannya tuntutan oleh penuntut umum.

\footnotetext{
25 Undang-Undang Republik Indonesia Nomor 31 Tahun 2014 Tentang Perubahan Atas UndangUndang Nomor 13 Tahun 2006 Tentang Perlindungan Saksi Dan Korban.

26 Maya Indah, Supra no 2, hlm 138.
} 


\section{Tinjauan Tentang Tindak Pidana Pencabulan Anak pada Putusan Nomor}

\section{3/Pid.Sus-Anak/2017/PN.Pbr}

Tindak Pidana Pencabulan sendiri adalah segala bentuk perbuatan mencari kenikmatan dengan menggunakan/melalui alat kelamin oleh dua orang (atau lebih) adalah perbuatan pencabulan. ${ }^{27}$ Dalam perbuatan untuk mencari kenikmatan secara seksualitas dapat dikatakan sebagai bagian dari pelanggaran kesusilaan dan kesopanan. Misalnya saja dengan cara menggosok-gosokkan alat kelamin, mengelus-elus alat kelamin atau antar kelamin, memegang buah dada atau bahkan mencium. ${ }^{28}$ Sehingga bagi Peneliti bahwa tindakan atau perbuatan yang dimaksudkan untuk mencari kenikmatan secara seksual dengan mengunakan atau melalui alat kelamin dengan cara mengosok, mengelus-elus, memegang, dan mencium merupakan Tindak Pidana Pencabulan.

Tindak Pidana Pencabulan termuat dalam pasal 289 Kitab Undang-Undang Hukum Pidana (KUHP) berbunyi :

Barang siapa dengan kekerasan atau ancaman kekerasan memaksa seorang untuk melakukan atau membiarkan dilakukan perbuatan cabul, diancam karena melakukan perbuatan yang menyerang kehormatan kesusilaan, dengan pidana penjara paling lama Sembilan tahun.

Pasal tersebut Terdapat pada bab XIV mengenai Kejahatan Terhadap Kesusilaan, yang mana apabila perbuatan tersebut dilakukan dengan cara kekerasan memaksa. Namun berbeda lagi apabila hal tersebut dilakukan dengan unsur subyek lain seperti dalam keadaan pingsan dan dilakukan pada sesorang yang belum usia 15 (Lima Belas) Tahun atau belum cukup untuk dikawin maka perbuatan cabul diancam dengan pidana penjara paling lama 7 (Tujuh) Tahun penjara.

Demikian pula terdapat alaternatif lain pada perbuatan Tindak Pidana Pencabulan yaitu pada usia Anak yang tercantum dalam Pasal 82 Undang-undang Nomor 23 Tahun 2002 tentang Perlindungan Anak sudah diatur mengenai sanksi bagi Pelaku dengan sengaja melakukan perbuatan yang berbunyi:

\footnotetext{
27 S.R. Sianturi, Tindak Pidana Di KUHP Berikut Uraiannya. Alumni Ahaen Patehaem, Jakarta, 1983, hlm 235.

28 Adami Chazawi, Tindak Pidana Mengenai Kesoponan, Grafindo, Jakarta, 2005, hlm 80.
} 
Setiap orang yang dengan sengaja melakukan kekerasan atau ancaman kekerasan, memaksa, melakukan tipu muslihat, serangkaian kebohongan, atau membujuk anak untuk melakukan atau membiarkan dilakukan perbuatan dipidana dengan pidana penjara paling lama 15 (lima belas) tahun dan paling singkat 3 (tiga) tahun dan denda paling banyak $\mathrm{Rp}$ $300.000 .000,00$ (tiga ratus juta rupiah) dan paling sedikit $\mathrm{Rp}$ $60.000 .000,00$ (enam puluh juta rupiah).

Terdapat jenis istilah mengenai pencabulan diantaranya yaitu :

a. Exhibitionism (sengaja memamerkan kelamin kepada orang lain);

b. Voyeurism (mencium seseorang dengan bernafsu);

c. Fonding (mengelus/ meraba alat kelamin seseorang);

d. Fellato (memaksa seseorang untuk melakukan kontak mulut). ${ }^{29}$

Pada putusan Nomor 13/Pid.Sus-Anak/2017/PN.Pbr yang Hakim Pengadilan Negeri Pekanbaru memutus Pelaku melanggar pasal 82 Ayat 1 UU RI No.35 Tahun 2014 Tentang Perlindungan Anak Jo Pasal 1 Ayat 1 UU RI No.11 Tahun 2012 Tentang sistem Peradilan Anak dengan memerintahkan agar Pelaku untuk dikeluarkan dari tahanan dengan syarat khusus supaya Anak menjalani 10 (bulan) Pembinaan di dalam Lembaga Sosial dan menjatuhkan pula pidana Pelatihan Kerja kepada Anak selama 2 (dua) bulan. Bagi Pelaku terdapat beberapa macam perlindungan dari mulainya penerapan pidana secara khusus melalui penyelesaian perkara Diversi ${ }^{30}$ maupun penyelesaian perkara secara Restoratif 31 . Dikarenakan Pelaku juga merupakan seorang Anak-Anak, maka dalam keterangan orang tua Anak dipersidangan dihubungkan dengan laporan LITMAS dari Bapas Klas II Pekanbaru yang menyaran supaya anak dibina dan dididik di Lembaga Penyelenggara Kesejahteraan Sosial (LPKS) yang ditempatkan di Panti Sosial Bina Remaja(PSBR) Rumbai-Pekanbaru, yang bertujuan:

a) Anak masih dapat dibina kearah yang lebih baik lagi;

29 Leden Marpaung, Kejahatan Terhadap Kesusilaan, Sinar Grafika, Jakarta, 2010, hlm 64

30 Diversi adalah pengalihan penyelesaian perkara Anak dari proses peradilan pidana ke proses di luar peradilan pidana, Bab I Pasal 1, Ketentuan Umum, Undang-Undang Republik Indonesia Nomor 11 Tahun 2012 Tentang Sistem Peradilan Pidana Anak.

31 Restoratif adalah penyelesaian perkara tindak pidana dengan melibatkan pelaku, korban, keluarga pelaku/korban, dan pihak lain yang terkait untuk bersama-sama mencari penyelesaian yang adil dengan menekankan pemulihan kembali pada keadaan semula, dan bukan pembalasan, Bab I Pasal 1, Ketentuan Umum, Undang-Undang Republik Indonesia Nomor 11 Tahun 2012 Tentang Sistem Peradilan Pidana Anak. 
b) Orang tua Anak mendukung keputusan Anak ditipkan di LPKS;

c) Anak telah menyadari kesalahannya dan berjanji tidak akan mengulangi perbuatan yang sifatnya melanggar hukum;

Sehingga terhadap Pelaku dijatuhkan pidana bersyarat sebagai ketentuan pasal 71 ayat (1) huruf a anagka (1) Undang-Undang Nomor 11 tahun 2012 Tentang Sistim Peradilan Pidana Anak yang lamanya akan ditentukan dalam amar putusan Nomor 13/Pid.Sus-Anak/2017/PN.Pbr. Namun pada putusan tersebut sama sekali tidak memuat pemenuhan hak-hak pada Anak Korban dalam tindak pidana cabul. Anak Korban menderita luka memar pada Anus, yang lebih dirasa putusan tersebut memberatkan dan kurang memuaskan rasa keadilan baik secara materiel kerugian biaya perawatan luka/medis serta psikis seperti trauma pada psikologis bagi diri Anak Korban, bahkan sampai pada lingkugan Keluarga sampai Masyarakat apabila Korban tidak segera mendapat hak-haknya seperti pemberian ganti kerugian restitusi, kompensasi serta rehabilitasi.

Hal tersebut justru akan menjadi preseden yang buruk bagi keadilan di Indonesia. Putusan tersebut bertentangan dengan Asas-asas pada sistem perlindungan Anak atau inkonsisten ${ }^{32}$ dalam pelaksanaan perkara pidana terutama pada Korban pencabulan bagi Anak. Peraturan mengenai Perlindungan Anak Korban terdapat hak-hak Korban dalam peradilan pidana yaitu meliputi Ganti Kerugian (Restitusi), Kompensasi dan Rehabilitasi.

Sedangkan perlindungan Korban pada UU Sistem peradilan Anak Pasal 18 menyebutkan bahwa Pembimbing Kemasyarakatan, Pekerja Sosial Profesional dan Tenaga Kesejahteraan Sosial, Penyidik, Penuntut Umum, Hakim, dan Advokat atau pemberi bantuan hukum mewajibakan untuk memerhatikan kepentingan korban. Hal ini Anak sebagai Pihak Korban dan/atau Anak berhak atas berbagai semua bentuk perlindungan maupun hak-hak lain yang diterima sebagai pihak Korban dan/atau Saksi yang diatur telah dalam ketentuan peraturan perundangundangan. Mengenai pelaksanaan restitusi bagi anak yang menjadi korban tindak pidana lebih khusus terdapat pada PP Nomer 43 Tahun 2017 yang merupakan

32 Artinya Tidak selaras atau tidak sesuai asas, Surawan Maktinus, Kamus Terapan, Persada Media Pustaka, Jakarta, 2008, hlm 30 
peraturan yang memuat mengenai pemenuhan hak-hak Anak Korban dalam tindak pidana, yaitu yang tercantum Pada Pasal 2 Ayat (1) PP Nomer 43 Tahun 2017 yang menyatakan bahwa Setiap orang yang menjadi Korban tindak pidana Anak maka Anak Korban berhak memperoleh ganti kerugian (Restitusi). Pelaksanaan Restitusi bagi Anak Korban tersebut mendasarkan pada PP Tahun 2017 Nomor 43 yang diharapkan dapat meringankan masalah serta mengurangi beban bagi pihak Anak Korban dalam mencapai tegaknya keadilan bagi Anak Korban yang telah menjadi Korban kejahatan Tindak Pidana Cabul. Namun hal tersebut tidak tercantum dan termuat dalam putusan Pengadilan Pekanbaru perkara Nomor 13/Pid.Sus-Anak/2017/PN.Pbr, Sehingga putusan tidak mencerminkan nilai keadilan bagi Anak Korban.

Perlohen hak Anak Korban mendapatkan kompensasi juga tidak termuat dalam Putusan Pengadilan seperti pada putusan Nomor 13/Pid.SusAnak/2017/PN.Pbr mengenai hak-hak yang seharusnya didapatkan oleh Korban. Mekanisme pengajuan perolehan Ganti Kerugian dan kompensasi tersebut yaitu diajukan oleh Korban kepada Pengadilan melalui LPSK. Dengan dalih tugas dan fungsi pada (LPSK) dalam membantu hak-hak dari Korban, tetapi ketika dalam praktiknya secara real Korban merasa rumit dengan persyaratan serta meknisme dalam memperoleh hak-hak kompensasi serta ketidaktahuan Korban dan/atau Keluarga Koban sehingga lebih memilih mengabaikan hak-hak atau asas yang terbaik bagi kepentingan Anak yang termuat pada sistem peradilan Anak.

Undang-Undang Nomor 31 Tahun 2014 atas perubahan Undang-Undang Nomor 13 Tahun 2016 Tentang Perlindungan Saksi dan Korban mengenai lembaga perlindungan saksi dan korban (LPSK) untuk lebih aktif tanpa menunggu adanya permohonan dari korban, dalam hal menanyakan kepada penyidik terkait dengan adanya tindak pidana atau meninggalkan pesan kepada penyidik apabila ada Visum et Repertum (Keterangan tertulis oleh Dokter) tindak pidana segera memberitahu kepada LPSK. Nantinya, LPSK agar nantinya lembaga perlindungan saksi dan korban aktif untuk mendatangi pelaku terkait meminta ganti kerugian 
dari pelaku maupun dari keluarga pelaku. Hal ini merupakan wujud perlindungan yang ideal terhadap korban ke depan. ${ }^{33}$

Pada ketentuan pidana bersayarat dalam Undang-Undang Perlindungan Anak tidak menjamin korban secara otomatis dapat memperoleh ganti kerugian apabila Hakim dalam menjatuhkan pidana bersyarat, sebab walaupun terdakwa telah diputus dengan pidana bersyarat, namun tidak ada kewajiban bagi Hakim memberikan ganti kerugian (restitusi) untuk mencantumkan syarat khusus pada putusan. ${ }^{34}$ Hal ini merupakan implikasi dari formulasi dari Pasal 98 KUHAP dengan peraturan mengenai Perlindungan Korban yang tidak taat asas atau inkonsistenterlihat memuat pedoman pemidanaan ganti kerugian pada proses peradilan sehingga mendudukkan korban sebagai forgotten person.

Dalam kesimpulannya bahwa hak dan eksistensi terhadap Anak Korban belum diberdayakan secara maksimal dalam proses pidana Anak, yang dalam tuntutan jaksa tidak pernah memberikan tuntutan ganti kerugian karena memang dalam pertimbangan Jaksa tidak ada kewajiban untuk menuntut ganti kerugian. Disisi lain dalam pertimbangan Hakim tidak ada sanksi pidana bagi Pelaku untuk mengganti kerugian pada Korban yang dikarenakan tidak ada dalam tuntutan Jaksa, ganti kerugian bisa diajukan ketika Korban mengajukan permohonan ganti kerugian, serta tidak ada kewajiban pada putusan untuk penyertaan tuntutan ganti kerugian Korban pada perkara pidana. Berdasar tersebut Hakim sangatlah berfikir legalistik formal, tanpa memberi pemikiran keadilan yang substansif untuk memberi perlindungan pada Korban. Putusan tersebut masih belum tercapai dalam penerapan pada Perlindungan Anak Korban, pada setiap kasus kekerasan seksual terhadap anak lebih condong pada pendekatan secara Retributive Justice ${ }^{35}$ yang lebih pada perlindungan kepada Pelaku dan mengabaikan hak-hak terhadap Anak Korban.

33 Jurnal dspace.uii.ac.id/Muhammad Khoirul Huda/Fakultas Hukum/ Universitas Islam Indonesia Yogyakarta/2018/Tesis. Perlindungan Hukum Korban Kejahatan ditinjau Dari Hukum Progresif.

34 Maya Indah, Supra No.2 hlm 159.

35 Retributve Justice artinya (menekankan keadilan pada pembalasan) Jurnal Veritas Et Justicia, Keadilan Restoratif Dan Pembatasan Diversi Pada Undang-Undang 11 Tahun 2012 Tentang Sistem Peradilan Pidana Anak, Volume 2-Nomor-2-304, Zenny Rezania Dewantary, hlm 15 


\section{Konsep Pemenuhan Hak Perlindungan Korban Pada Proses Peradilan Tindak Pidana Cabul Anak secara Progesif}

Penerapan hukum progresif, yang pada dasarnya terarah kepada para pelaku hukum ini, diharapkan akan dapat mengarahkan hukum yang dihasilkan oleh proses legislasi, yang cenderung elitis, untuk mengarah pada kepentingan keadilan dan kesejahteraan rakyat banyak Hukum Progresif menempatkan hukum sebagai suatu institusi manusia, yang saling melengkapi satu dengan lain dengan aspek manusia, baik dalam hubungan antar manusia maupun masyarakat yang lebih luas. ${ }^{36}$

Untuk menerapkan hukum progresif pada pemenuhan hak perlindungan Korban Anak yaitu dengan menggunakan 3 (tiga) macam pendekatan penelitian. Pertama, studi kasus (case study), pada penelitian ini fakta materiel pada Putusan Nomor 13/Pid.Sus-Anak/2017/PN.Pbr HakimPengadilan Negeri Pekanbaru menjadi rujukan dalam membangun argumentasi. Di dalam civil law hukum Indonesia dilihat konsiderans "Menimbang" pada "Pokok Perkara". Dengan kata lain ketentuan-ketentuan peraturan perundang-undangan yang menopang argumentasi hukum pada fakta materiel yaitu pada kasus (putusan pengadilan). Kedua, Pendekatan Konseptual, pendekatan ini manakala dilakukan memang belum ada aturan hukum atau tidak ada aturan hukum untuk masalah yang dihadapi. Peneliti merujuk pada prinsip-prinsip hukum, serta konsep yang terdapat di dalam undang-undang. ${ }^{37}$ Ketiga, pendekatan perundang-undangan (Statue Approach), pendekatan tersebut penyusun akan mendapat informasi dari berbagai aspek dalam menganalisis permasalahan tersebut. Dalam metode pendekatan perundang-undangan peneliti pada pemahaman hierarki, dan asasasas dalam peraturan perundang-undangan yang mencerminkan gagasan pada Asas Keadilan. Maka konsep pemenuhan hak perlindungan Korban pada Proses Peradilan Tindak Pidana Cabul Anak secara Progesif yaitu :

Diana E. Rondonuwu, Hukum Progresif: Upaya Untuk Mewujudkan Ilmu Hukum Menjadi Sebenar Ilmu Pengetahuan Hukum. Lex Administratum, Vol. II/No.2/Apr-Jun/2014, hlm 1

Peter Mahmud Marzuki, Penelitian Hukum, Kencana, Jakarta, 2016, hlm. 177-178. 
Pertama, Untuk menyempurnakan KUHAP mengenai hak-hak Anak Korban Restitusi, Kompensasi maupun Rehabilitasi dalam pandangan hukum Progresif perlu adanya cross examinitation ${ }^{38}$ yang merupakan adopsi dari sistem anglo saxon perlu dirumuskan dalam KUHAP ${ }^{39}$, maksud proses tersebut ialah untuk memperoleh pemenuhan hak-hak Korban yang lebih memerhatikan kepentingan Anak Korban yaitu melalui Jaksa yang termuat dalam tuntutan Jaksa pada proses peradilan Anak, atas pertimbangan tersebut Hakim dapat memuat pemenuhan Anak Korban putusan tersebut tanpa menunggu putusan terlebih dahulu dan tanpa harus mengajukan kepada LPSK. Sehingga hak restitusi atau ganti kerugian dapat dijalankan sesuai asas peradilan cepat, sederhana dan biaya ringan. selain itu dapat juga melalui pendampingan hukum khusus pada Anak Korban dibandingkan dengan LPSK yang bukan merupakan aparat penegak hukum.

Kedudukan korban dalam peradilan pidana sebagai pihak pencari keadilan selama ini terabaikan. Apabila dikaji dari tujuan pemidanaan dalam hukum pidana positif, pelaku kejahatan lebih mendapat perhatian seperti rehabilitasi, treatmen offenders readaptasi sosial pemasyarakatan dan lain-lain. Pengelolaan dalam peradilan pidana adalah sebagai suatu sistem menerima kedudukannya sebagai subsistem dari sistem yang besar yaitu masyarakat. ${ }^{40}$ Sehingga bekerjanya peradilan pidana harus difungsikan sebagai administrasi keadilan yang harus mampu menyelesaikan permasalahan hukum pidana baik dalam lembaga maupun pranatanya secara adil di masyarakat. ${ }^{41}$ Bekerjanya penegak hukum dalam peradilan pidana baik itu polisi, jaksa, maupun hakim dalam menangani perkara pidana merupakan sebagai suatu birokrasi subsistem sosial yang bekerja dalam lingkungannya, dan mempunyai cara dalam mencapai tujuan. Hukum tersebut tertuang dalam landasan normatif yaitu KUHP dan KUHAP, serta perundangundangan lainnya sebagai instrumen bekerjanya peradilan pidana.

\footnotetext{
38 Cross examinitation merupakan proses tanya jawab antara penegak hukum, Hakim, Jaksa Penuntut Umum dan Pembela dengan Terdakwa, M. Marwan dan Jimmy, Kamus Hukum, Reality Publisher, Surabaya, 2009, hlm 497.

39 Maya Indah, Supra no. 2, hlm 180.

40 Sahetapy, Bunga Rampai Viktimisasi, Pustaka Sinar Harapan, Jakarta 1995, hlm 7.

41 Maya Indah, Supra no. 2, hlm 9.
} 
Kelemahan KUHAP tidak memperkenankan kepada Korban untuk mengajukan gugatan ganti kerugian yang bersifat immateriil secara jelas dan terbatas, dalam pasal 99 Ayat 2 dan Pasal 100 KUHAP menyatakan bahwa penggantian biaya ini hanya pada penetapan hukuman penggantian yang telah dikeluarkan oleh pihak yang dirugikan apabila Jaksa Penuntut Umum tidak hadir maka pupus sudah harapan Korban maupun Keluarga Korban sebagai pihak yang dirugikan, belum lagi apabila pihak yang dirugikan tidak mengetahui mengenai informasi Penggabungan Perkara Gugatan Ganti Kerugian. Untuk itulah perlunya Cross examination diperlukan sebagai penilaian Hakim dalam merumuskan, mempertimbangkan, dan menetapkan jenis dan jumlah ganti kerugian Korban pada Proses Peradilan Pidana. Hal ini juga perlu didahului dengan kemauan Jaksa untuk memperhatikan kepentingan Korban, disamping Hak Korban perlu untuk didampingi Penasihat Hukum Khusus Anak, yang juga harus diakomodasi seperti halnya Pelaku yang mendapatkan Hak untuk didampingi Penasehat Hukum.

Kedua, Restitusi/Ganti Kerugian ini dapat berjalan sebagaimana mestinya, perlu diterapkan Asas Peradilan Cepat, Sederhana dan Biaya Ringan. Secara Konkret Asas Peradilan Cepat, Sederhana dan Biaya Ringan dimaksudkan agar orang-orang yang terkait di dalam peradilan tidak diperlakukan dan diperiksa sampai berlarut-larut, kemudian dapat memperoleh kepastian secara prosedural terhadap hukum yang ada, proses administrasi ringan, serta tidak memboroskan sumber daya yang terdapat selama proses pemeriksaan. ${ }^{42}$ Kaitannya dengan keberadaan secara cepat dan sederhana sehingga tidak membuat mereka menjadi tidak nyaman dan merasa terbebani proses pemenuhan hak-hak yang seharusnya diberikan oleh Korban.

Ketentuan pada Peraturan Pemerintah Nomer 43 Tahun 2017 tentang pelaksanaan restitusi bagi anak yang menjadi korban menjadikan hak-hak Anak Korban melalui LPSK sebagaimana yang dimaksud dalam pasal 6 menjadi fakultatif karena sifatnya bergantung pada keputusan lembaga tersebut. Hak-hak seyogyanya bersifat fundamenal tanpa mendasar pada keputusan LPSK. Hal ini

42 Marlina dan Asmiati Zuliah, Hak Restitusi Terhadap Korban Tindak Pidana Perdagangan Orang, PT Refika Aditama, Bandung, 2015, hlm 123. 
tentu bertentangan dengan KUHAP terutama pada pasal 98 yang mengatur penggabungan perkara pidana dengan ganti kerugian. Dalam RUU Penghapusan Kekerasan Seksual pasal 49 mengenai putusan ganti kerugian yang menyatakan bahwa melalui tuntuan jaksa yang kemudian Hakim menetapkan putusannya mengenai jenis serta jumlah ganti kerugian. Dari pasal tersebut lebih tercapainya hak-hak pemenuhan perlindungan Anak Korban khususnya Anak sebagai Korban kekerasan seksual yaitu cabul. Aturan UU mengenai sistem peradilan Anak serta PP mengenai pelaksanaan Restitusi Anak Korban seharusnya disesuaikan dengan sistem peradilan yang progresif agar terciptanya rasa keadilan.

Pada Undang-Undang Nomor 31 Tahun 2014 Tentang Perubahan Atas Undang-Undang Nomor 13 Tahun 2006 Tentang Perlindungan Saksi Dan Korban, maka peneliti merangkumnya dalam skema proses peradilan Anak dalam bagan berikut:

\section{Bagan 2: Skema Alur Proses Persidangan Pidana Anak dalam perkara pencabulan} secara Progersif

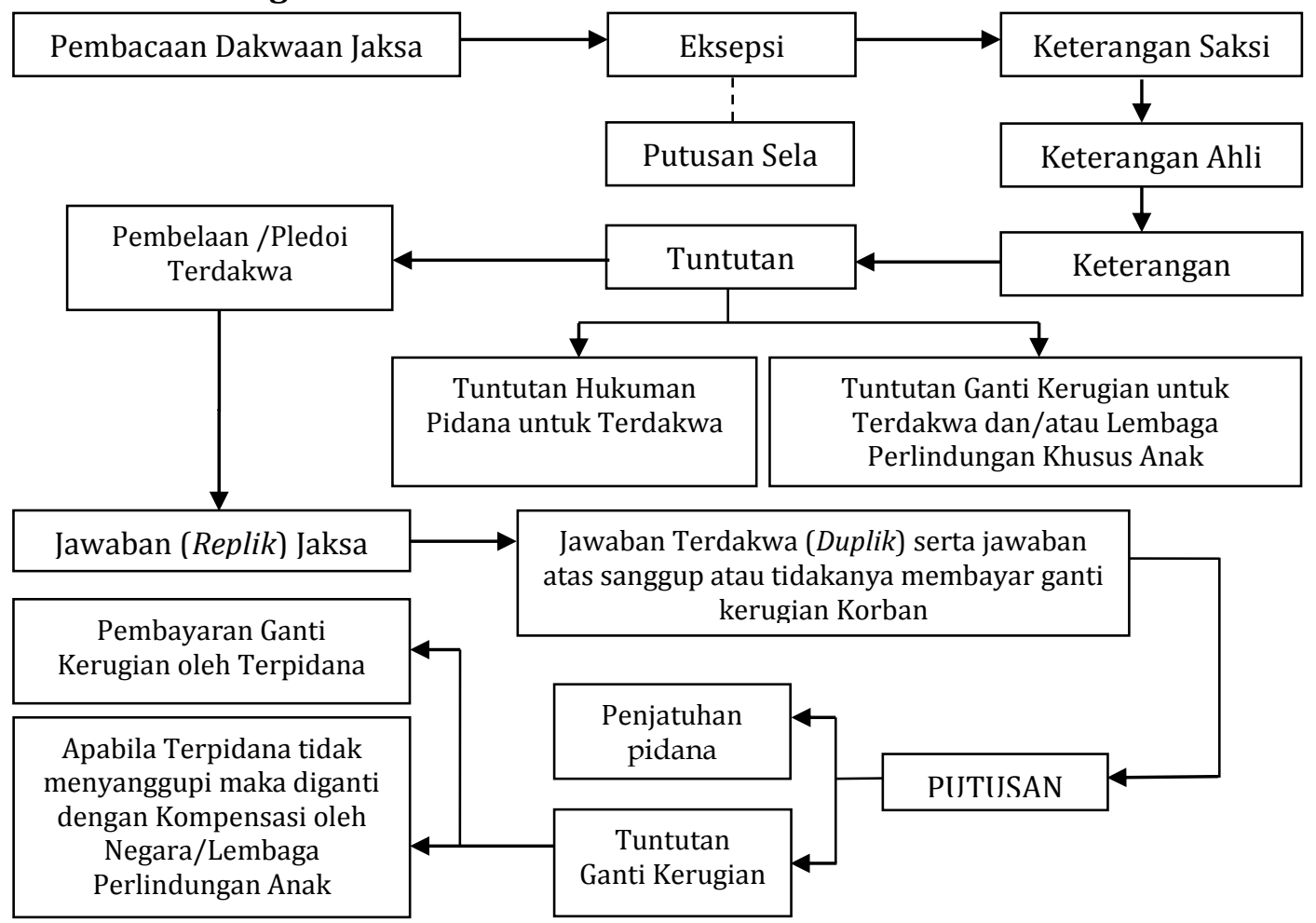

Sumber: Diolah penulis dari 31 Tahun 2014 Tentang Perubahan Atas Undang-Undang Nomor 13 Tahun 2006 
Bagan di atas menggambarkan bahwa bekerjanya peradilan pidana sesuai keadilan pada Anak Korban yang meliputi response selecetd assasment dari penegak hukum yang dimulai dari kepolisian, LPSK serta Penuntut Umum sebagai extended responses yang akan disampaikan pada proses peradilan pidana Anak. Perspektif diatas memunculkan pentingnya aspek akuntabilitas untuk peradilan pidana dan implikasinya terhadap kontrol dan tanggung jawab institusi. Hal tersebut dapat dikaji dari prilaku penegak hukum, keputusannya atau peristiwa dalam rangka pertanggungjawaban moral dan hukum yang merefleksikan fungsi perlindungan, pengayoman, dan keadilan dari proses peradilan pidana, yang tentunga dapat dipertegas dan dijiwai dalam aturan perundang-undangan. Namun, dalam rangka pencapaian perlindungan Anak Korban maka yang perlu diperhatikan adalah keadilan substansial yang memperhatikan nilai-nilai humanisme.

Pengakomodasian ganti kerugian pada hak-hak Anak korban secara substansial memiliki konsekuensi bahwa politik hukum pidana bertujuan pada konsep the systematic resocialization of the offender yang mengikhtiarkan perlindungan pada kejahatan yang mencakup haknya sebagai manusia, walaupun ia harus membayar kejahatan yang dilakukannya. ${ }^{43}$ Keseimbangan kepentingan pelaku dan korban dalam rangka perlindungan hak-hak asasinya adalah menjadi perspektif bekerjanya peradilan pidana.

Secara Progressive untuk menerapakan konsep the systematic resocialization of the offender perlu dipertegas pada rancangan aturan UndangUndang Nomor 11 Tahun 2012 Tentang Sistem Peradilan Pidana Anak atau pada Undang-Undang Nomor 31 Tahun 2014 Tentang Perubahan Atas Undang-Undang Nomor 13 Tahun 2006 Tentang Perlindungan Saksi Dan Korban denagn memberikan ruang pada Pasal mengenai jenis ganti kerugian yang meliputi : a) Uang sebagai ganti kerugian materiil dan immaterial; b) Layanan pemulihan yang dibutuhkan Korban dan/atau Keluarga Korban; c) Permintaan maaf kepada Korban dan/atau Keluarga Korban; dan d) Pemulihan nama baik Korban dan/atau

43 Ancel, Social Defence a Modern Approach to Criminal Problems, London : Foreward Leon. Trans J, p. 17. 
Keluarga Korban.

Sebagai tata cara pelaksanaaanya dapat mengadopsi Pasal 48 RUU Penghapusan Kekerasan Seksual yang diterapkan pada Peraturan Pemerintah Nomer 43 Tahun 2017 tentang pelaksanaan restitusi bagi anak yang menjadi korban yaitu mengenai Hak Korban Anak dalam Penuntutanya, Penuntut Umum wajib mengajukan Ganti Kerugian dalam surat tuntutan. Serta terdapat Putusan Ganti Kerugian yang dalam menetapkan putusan tentang jenis dan jumlah Ganti Kerugian, yang majelis hakim wajib memeriksa kembali jenis dan jumlah Ganti Kerugian yang diajukan penuntut umum.

Maka dari itu Perlu untuk diterbitkan Rancangan Undang-Undang mengenai Pelindungan Korban Anak serta pelaksanaan restitusi bagi anak yang menjadi korban sebagai hukum pidana khusus yang nantinya akan memunculkan terobosan dalam sistem peradilan pidana dengan tujuan agar Korban khususnya Anak dapat mengikuti proses peradilan pidana yang berpusat pada upaya pemenuhan hak Korban dan upaya mendekatkan Korban kepada keadilan. Selain merumuskan ancaman pidana pokok dan pidana tambahan yang bertujuan retributif sekaligus rehabilitatif, pemidanaan yang dijatuhkan akan disertai pemberatan apabila korban adalah anak. ${ }^{44}$ Mengingat tindak pidana pencabulan bagi Anak Korban yang berada dalam kondisi relasi kuasa yang timpang dalam keadilan dengan Pelaku kejahatan pada proses Peradilan terlebih apabila Korban sebatas Saksi, diterbitkan Rancangan Undang-Undang mengenai Pelindungan Korban Anak serta pelaksanaan restitusi bagi anak yang menjadi korban akan membangun pembaharuan hukum khususnya terkait social deffence perlindungan Korban dan pemulihan bagi korban pencabulan bagi siapapun korban, termasuk anak.

44 Website Komisi Nasional Perempuan naskah publik mengenai Rancangan Undang-Undang Perlindungan Kekerasan Seksual Anak dan Perempuan, diakses pada 21 Februari 2020, Link : https://www.komnasperempuan.go.id/file/pdf_file/Isu\%20Prioritas\%20Kekerasan\%20Seks ual/7.RUU\%20KS-UU\%20PERLINDUNGAN\%20ANAK-BAG\%207.pdf 


\section{Penutup}

Hak dan eksistensi terhadap Anak Korban belum diberdayakan secara maksimal dalam proses pidana Anak, yang dalam tuntutan jaksa tidak pernah memberikan tuntutan ganti kerugian karena memang dalam pertimbangan Jaksa tidak ada kewajiban untuk menuntut ganti kerugian. Disisi lain dalam pertimbangan Hakim tidak ada sanksi pidana bagi Pelaku untuk mengganti kerugian pada Korban yang dikarenakan tidak ada dalam tuntutan Jaksa, ganti kerugian bisa diajukan ketika Korban mengajukan permohonan ganti kerugian, serta tidak ada kewajiban pada putusan untuk penyertaan tuntutan ganti kerugian Korban pada perkara pidana, sehingga hak Anak Korban pada peraturan perlindungan Anak serta peradilan pidana Anak terbatas. Konsep Pemenuhan Hak Perlindungan Korban Pada Proses Peradilan Tindak Pidana Cabul Anak secara Progesif yaitu Pertama, Untuk menyempurnakan KUHAP mengenai hak-hak Anak Korban Restitusi, Kompensasi maupun Rehabilitasi dalam pandangan hukum Progresif perlu adanya cross examinitation diperlukan sebagai penilaian Hakim dalam merumuskan, mempertimbangkan, dan menetapkan jenis dan jumlah ganti kerugian Korban pada Proses Peradilan Pidana. Hal ini juga perlu didahului dengan kemauan Jaksa untuk memperhatikan kepentingan Korban, disamping Hak Korban perlu untuk didampingi Penasihat Hukum Khusus Anak, yang juga harus diakomodasi seperti halnya Pelaku yang mendapatkan Hak untuk didampingi Penasehat Hukum. Kedua, Secara Progressive untuk menerapakan konsep the systematic resocialization of the offender perlu dipertegas pada rancangan aturan Undang-Undang Nomor 11 Tahun 2012 Tentang Sistem Peradilan Pidana Anak atau pada Undang-Undang Nomor 31 Tahun 2014 Tentang Perubahan Atas Undang-Undang Nomor 13 Tahun 2006 Tentang Perlindungan Saksi Dan Korban denagn memberikan ruang pada Pasal mengenai jenis ganti kerugian yang meliputi : a) Uang sebagai ganti kerugian materiil dan immaterial; b) layanan Pemulihan yang dibutuhkan Korban dan/atau Keluarga Korban; c) permintaan maaf kepada Korban dan/atau Keluarga Korban; dan d) Pemulihan nama baik Korban dan/atau Keluarga Korban. Dengan sebagai tata cara pelaksanaaanya dapat mengadopsi Pasal 48 RUU Penghapusan Kekerasan Seksual 
yang diterapkan pada Peraturan Pemerintah Nomer 43 Tahun 2017 tentang pelaksanaan restitusi bagi anak yang menjadi korban yaitu mengenai Hak Korban Anak dalam Penuntutanya, Penuntut Umum wajib mengajukan Ganti Kerugian dalam surat tuntutan. Serta terdapat Putusan Ganti Kerugian yang dalam menetapkan putusan tentang jenis dan jumlah Ganti Kerugian, yang majelis hakim wajib memeriksa kembali jenis dan jumlah Ganti Kerugian yang diajukan penuntut umum.

\section{Daftar Pustaka}

\section{Buku:}

Adami Chazawi, Tindak Pidana Mengenai Kesoponan, Grafindo, Jakarta, 2005. Arif Gosita, Peradilan Anak di Indonesia, Mandar Maju, Bandung, 1996.

Bahder Johan Nasution, Hukum Dan Keadilan, Mandar Maju, Bandung, 2015.

Barda Nawawi, Kebijakan Legislatif Dalam Penanggulangan Kejahatan Dengan Pidana Penjara, Ananta, Semarang, 1994.

Bambang Waluyo, Viktimologi Perlindungan Korban \& Saksi, SinarGrafika, Jakarta 2011.

Gosita Arif, Masalah Perlindungan Anak, Akademika Presindo, Jakarta, 1989.

Leden Marpaung, Kejahatan Terhadap Kesusilaan, Sinar Grafika, Jakarta, 2010

Irma Setyowati, Aspek Hukum Perlindungan Anak, BumiAksara, Jakarta, 2010.

Marlina dan Asmiati Zuliah, Hak Restitusi Terhadap Korban Tindak Pidana Perdagangan Orang, PT Refika Aditama, Bandung, 2015.

Maya Indah, Perlindungan Korban Suatu Perspektif Viktimologi Dan Kiminologi, Kencana, Jakarta, 2014.

Peter Mahmud Marzuki, Penelitian Hukum, Prenadamedia Group, Jakarta, 2005.

Suteki, Masa Depan Hukum Progesif, Thafa Media, Jakarta, 2015.

Shanty, Wanita Dan Anak Dimata Hukum, Liberty, Jakarta, 2004.

Soerjono Soekanto, Pengantar Penelitian Hukum, UI Press, Jakarta, 1982.

Sinolungan, Psikologi Perkembangan Peserta Didik, Gunung Agung, Jakarta, 1997.

Sahetapy, Bunga Rampai Viktimisasi, Pustaka Sinar Harapan, Jakarta, 1995.

Siswanto Sunarso, Viktimologi Dalam Sistem Peradilan Pidana, Sinar Grafika, Jakarta, 2012.

Sudikno Mertokusumo, Mengenal Hukum, Liberty, Yogyakarta, 2002.

\section{Makalah:}

Satjipto Raharjo. Menuju Produk Hukum Progesif, Makalah Diskusi Terbatas Pada Fakultas Hukum Undip. Semarang, 24 Juni 2004, https://books.google.co.id 
Jurnal:

Diana E. Rondonuwu, Hukum Progresif: Upaya Untuk Mewujudkan Ilmu Hukum Menjadi Sebenar Ilmu Pengetahuan Hukum. Lex Administratum, Vol. II/No.2/Apr-Jun/2014.

Journal Universitas Airlangga /AstridAyuPravitari/FakultasHukum/Universitas Airlangga/2018/Tesis. Anak yang berkonflik dengan Hukum yang melakukan pemerkosaan terhadap Anak

Jurnal Tesis dspace.uii.ac.id/Muhammad Khoirul Huda/Fakultas Hukum/ Universitas Islam Indonesia Yogyakarta/2018/Tesis. Perlindungan Hukum Korban Kejahatan ditinjau Dari Hukum Progresif.

Jurnal Veritas Et Justicia, Volume 2-Nomor-2-304, Zenny Rezania Dewantary, Keadilan Restoratif Dan Pembatasan Diversi Pada Undang-Undang 11 Tahun 2012 Tentang Sistem Peradilan Pidana Anak.

Nyoman Mas Aryani, Perlindungan Hukum Terhadap Anak Sebagai Korban Kekerasan Seksual Di Provinsi Bali, Jurnal Ilmiah Fakultas Hukum Universitas Udayana Kertha Patrika Volume 38, Nomor 1, Januari-April 2016.

\section{Peraturan Perundang-undangan:}

Kitab Undang-Undang Hukum Pidana;

UU Nomor 8 Tahun 1981 tentang Kitab Undang-undang Hukum Acara Pidana;

Undang-Undang Nomor 31 Tahun 2014 tentang perubahan atas Undang Undang nomor 13 Tahun 2016 tentang Perlindungan Saksi dan Korban;

Undang-Undang Nomor 35 Tahun 2014 tentang perubahan atas Undang Undang nomor 23 Tahun 2002 tentang Perlindungan Anak;

Peraturan Pemerintah Nomer 43 Tahun 2017 tentang pelaksanaan restitusi bagi anak yang menjadi korban tindak pidana;

Peraturan Pemerintah Nomor 44 Tahun 2008 tentang Pemberian Kompensasi, Restitusi dan bantuan kepada saksi dan korban;

Undang-Undang Nomor 31 tahun 2016 tentang Perlindungan saksi dan korban;

Undang-Undang Nomer 8 Tahun 1981 tentang Kitab Undang-Undang Hukum Acara Pidana;

Putusan Pengadilan:

Putusan Nomor 13/Pid.Sus-Anak/2017/PN.Pbr HakimPengadilan Negeri Pekanbaru.

\section{Website:}

https://www.komnasperempuan.go.id/file/pdf_file/Isu\%20Prioritas\%20Kekeras an\%20Seksual/7.RUU\%20KS-UU\%20PERLINDUNGAN\%20ANAK-

BAG\%207.pdf 